\title{
How Can Teacher Trainers Address Inequalities in the Curriculum and in Society? The Lessons (in Theory and in Practice) From Tthe South East Europe Case
}

\author{
Aida McLeod \\ School of Linguistics \\ Erican College, Kuala Lumpur, Malaysia \\ E-mail: mcleodaida@gmail.com \\ Ian S. McLeod \\ School of Linguistics \\ Erican College \\ Kuala Lumpur, Malaysia
}

Received: 21-07-2014

doi:10.7575/aiac.ijalel.v.4n.1p.226
Accepted: 08-09-2014

Published: 01-01-2015

URL: http://dx.doi.org/10.7575/aiac.ijalel.v.4n.1p.226

\begin{abstract}
The curriculum should pay particular attention to ethnic, gender, and other forms of social difference and inequality. At the same time, it should stress the importance of studying, ideals and experiences of what it means to be a teacher. Courses should be designed to explore these issues in both historical and contemporary settings. Although the concentration needs to be on the content, a good curriculum needs to be designed to foster a community of learning among people and at the same time to offer considerable flexibility and intellectual diversity (J. Yalden, Long, Micheal H., Richards, Jack C. 2001). In this paper we will analyze key aspects of, and changes in, the curriculum, social and economic development in South Eastern Europe in the last twenty years. Major issues covered in this paper will be: the impact of communism on society; political and education reform; the problems of people with special needs; the changing role and status of minority groups and the introduction of a service learning project in the curriculum.
\end{abstract}

Keywords: Service-learning; education, curriculum, creativity

\section{Introduction}

In our work we start out from the fundamental axiom that the character of any country, nation or society can be measured by the way it treats its minorities, and furthermore that this can best be discovered by examining its education curriculum, since the school curriculum is where its ideology of tolerance or otherwise towards diversity is reflected and also implemented.

The South East European University is located in an area of Macedonia where there are no educational programs for students with special needs. There is a Department of "Defectology"1 in Skopje (Public University of Cyril and Methodius). According to the New Law on higher education from 14.03.20082 people with Special Needs can attend public schools for free; however none of them is physically accessible for these people.

\section{First steps}

\subsection{First Service Learning project}

In 2004 a service learning project was successfully implemented in the curriculum of the Teacher Training Department, South East European University: this was the first time such a project had ever been carried out at SEEU or any other university in South Eastern Europe. This innovative methodology was successfully implemented because of support given by the management of the SEEU and in particular by the Rector Zamir Dika. SEE University is unlike other public Universities in the region, where it is much more difficult to implement innovative teaching techniques.

\subsection{Obstacles to change}

The main obstacle for this, as stated by a Montenegrin professor of Education Milic Sasa, "has been resistance from the teacher education field, University institutions are conservative and traditional, following the Herbart class/lesson organization (present the information, help students analyze it and compare and contrast it to other information, develop a general principle, and apply the information) and espousing the obsolete communist/socialist views of education and society. These university institutions are dedicated to studying more traditional pedagogical and psychological theories of education (those of Herbart, Komenski, Pestalozzi, Rousseau, etc.). Recent theoretical views are absent, as are practical work and practical training of future teachers for their profession. Even today, students graduate from a faculty of education without spending a single day in a school classroom" (Milic 2014) 


\subsection{Benefits of the change}

The innovation to the curriculum proved to be very useful for students since this approach to teaching/learning provided opportunities to scaffold students' learning and facilitate individually-appropriate stages of learning tailored to meet the needs of the students. This practical approach to curriculum design was highly regarded by the professionals in South Eastern Europe who attended the workshops "Equal Access through Service Learning for Persons with Disabilities in Education," a research project funded by the United States Bureau for Development of Education's "Enhancing Accessibility of Higher Education to the Disabled" program, on the topic, many of whom have gone on to apply this innovative strategy in their curriculum. Students, for the first time, were involved in an active academic community that is characterized by a willingness to introduce new programs that provide opportunities for students that extend the traditional curriculum.

\section{Details of the change}

In the curriculum, we decided that the students needed to do more of the work of making sense of the course than we usually asked them to do and so the writing assignments ( $10 \%$ of the total grade) asked students to make connections -among the readings, across the modules, between contemporary events and historical ones, among analytical categories (race, class, gender).

In addition to introducing a service learning project in the curriculum, we planned a number of other pedagogical innovations including "directed" discussion sections focused on a particular student's experiences (in addition to the week's reading); panel discussions where several Peace Corps volunteers and students with disabilities interacted around a topic; shorter guest lectures (from experts and officials) with more time for student questions; and "minilectures" of ten to twenty minutes from experts in particular subjects. This too was an innovation: in the other public universities of Macedonia currently, "discussion" is not much different from the traditional methodology observed in the Yugoslav period and aptly described by Georgeoff:

In Yugoslav schools, discussion usually employs a type of Pavlovian stimulus-response approach; the teacher asks questions to which pupils give predetermined responses they have learned from class lectures or by reading the textbook. During the discussion period, pupils seldom ask their teacher questions about some point in the lesson; and almost never is there direct communication ... between one pupil and another. (Qtd. In Sobe, 2007:52)

We previously agreed that panel discussants would each speak for five minutes to leave time for discussion among the group and that all guest lectures would be only 30 minutes long to leave time for questions (in a 60 minute class). Although we never found time to meet before the lectures or panels, we maintained a lively email correspondence to ensure that each member of the panel and the presenters knew how the course was going and how their presentation fitted. Peace corps volunteers gave 5 lectures; there were three panel discussions (one in each module); three guest lectures (including two by NGO leaders); three "mini lectures" of about 10-20 minutes each; one field trip (guided) and a final - end of the semester event in the lecture hall.

\section{Outcomes of the change}

This complex schedule took some time to be developed but it resulted in a great diversity of presentations and lively class sessions. Students got only minimal advance notice of what would happen in each class session and seemed to like the guest speakers as well as the range of voices, approaches, and formats.

\section{General nature of the Needs Analysis and Course Design (NACD) course}

The course is orientated towards pragmatic aspects of teaching, especially needs analysis and course design, starting by general consideration and continuing with more and more specific aspects. Students are introduced to the different kinds of needs: individual and social needs, the impacts of needs analysis on course design: impact on the definition of objectives and contents, impact on the pedagogy and methodology. We also work on kinds of data on which needs analysis operates: wishes, performances, student's awareness of lacks, metacognitive skills.

\section{General nature of service learning}

The main aim of service learning is for students to take the learning which they have acquired in the classroom and apply it in the community. Students work in organized projects where they apply skills and knowledge, critical thinking and reflection in order to meet an identified need in their community (Anderson, Swick \& Yff, 2001; Rehling 2000; Russell, 2007; Wells \& Graber, 2004). The basic components of a service-learning project are:

1) The project should address a need of the broader community

2) The project should meet curricular objectives (Learn \& Serve America, 2008).

3)

\section{The NACD project description}

\subsection{The first option}

The service learning project implemented by the NACD course-takers was titled: "How to Accommodate Students with Special Needs". Students were given two service learning options to choose from. The first option given to students was to write a lesson plan. They had to imagine they were to teach a general education TEFL class. Within this class there are three students with three different disabilities. Students were asked to develop specific case studies for each of the students, as well as to develop a basic TEFL lesson plan (on a topic of their choice) including modifications and 
alternative assessments for the students with special needs.

\subsection{The assessment structure for the first option}

Given that the main goal of assessment is to improve learning, increasing formative assessment of service-learning also provides feedback necessary to improve the quality of service-learning practice and at the same time enhance student learning. The nature of service-learning demands authentic forms of assessment because we need to capture the real world transfer skills that our students are developing. The students' final lesson plan document was evaluated based on the following criteria:
A. Creativity $25 \%$
B. Realistic case studies $25 \%$
C. Lesson plan and modifications $25 \%$
D. Overall organization (clear and consistent) $25 \%$

Here is the detailed explanation of each of the criteria:

A. Creativity: your writing is original; you have put thought into your writing; you have added your personal touch. If you use other sources of information state them properly and provide internet website specifically; do not write e.g. www.google.com, be more specific.

B. Realistic case studies: Case studies should be as realistic and detailed as possible. The description of the student should include

$\square$ Name, grade-level/age, disability, personality traits, academic ability

$\square$ Accurate characteristics of specific disability (as found in PowerPoint from class, or independent research - must be stated in reference section)

\section{Lesson plan and modifications:}

$\square$ The lesson plan should be creative and consistent to the format used in courses. -

Modifications should be specifically suited to disabilities including any adapted materials needed

$\square$ Three to four specific modifications and alternative assessments per student

D. Overall organization: The paper should be clear and consistent. Double-check your writing, read it out loud to make sure it makes sense.

The lesson plan document should be 5-7 pages, 1st page cover page and the end include a reference section.

\subsection{The second option}

The second service-learning project option given to students was to create a 3 or 4 fold brochure in English, using Microsoft Publisher, highlighting an issue related to Special Needs. For example, it could be on "What is Autism" directed towards teachers, or it could be about "Sports and the Physically Disabled" directed towards coaches. Students pick the topic, but it must be related to Special Needs.

\subsection{The assessment structure for the second option}

The grading of the students' brochure is based on the following categories and percentages:
A. Design/Creativity $-10 \%$
B. Grammar $-30 \%$
C. Content $-30 \%$
D. Relevance $-30 \%$

Here is the detailed explanation of each of the criteria:

A. Design/Creativity: The overall design of the brochure is evaluated. For example, is the brochure appealing to the target audience, are the pictures chosen appropriate for the subject matter, etc.

B. Grammar: Spelling, punctuation, word choice and fluency of sentences is evaluated.

C. Content: The target audience (teachers, parents, etc) must have been stated, either in the student's brochure if appropriate, or in the email in which the assignment is submitted. The content is evaluated to see if the brochure is clear as to what point it is trying to present.Also it is looked at to see if it is informative and whether the information in it is correct for the topic being presented.

D. Relevance: This is based on how well the final product meets the requirements of the assignment. For example, is the subject of the submitted work related to special needs, is the final product a brochure; etc. I have developed a rubric so that students are better informed about how they will be evaluated: see Appendix 1.

\section{Conclusion}

When working with students with disabilities, students refine essential skills associated with their teacher training studies: to apply effective communication techniques and include a variety of activities in their lessons. While completing this service-learning project, students apply effective problem solving and thoughtful decision-making skills 
in a community setting in addition to learning behavior management strategies (i.e., positive reinforcement, negative reinforcement, punishment and so on), as well as extracting meaning from an experience by engaging in effective selfreflection. What is more, students engage in new experiences and assume unfamiliar roles, accept challenges in the process and gain an understanding of cultural diversity, civic engagement and social justice issues facing their communities. By engaging in a service-learning project, students research and analyze social justice issues affecting marginalized populations. In writing their lesson plans, they explore and clarify the implications of inequalities and other community issues for the curriculum and for education generally.

\section{References}

Ammon, M. (1998). Probing and Promoting Teachers` Thinking about Service-Learning: Toward a Theory of Teacher Development. 1998 in S. H. Billing and A. Furco (eds.), Service Learning through a Multidisciplinary Lens. Greenwich, CT: Information Age Publishing. 33-54.

Anderson, J. B., Swick K. J., Yff J. (2001). Service-Learning in Teacher Education. American Association of Colleagues for Teacher Education. New York: University of California Press.

Bringle, R. G. and Hatcher J. A. (2004). Implementing Service Learning in Higher Education. Journal of Higher Education, 67: 221-239.

Chuleva, Galina, Phillips, Rob. J. (2014). Educating for Democracy: Designs for Learning in the Balkans and Beyond. Peer Review, 2(12).

Dewey, J. (1976). The school and society. In J. A. Boydston (Ed.), John Dewey: The middle works. (2 ${ }^{\text {nd }}$ ed) 1899-1924 (Vol. 1, pp. 1-109). Carbondale: Southern Illinois University Press.

Goleman, D. (2005). Emotional Intelligence. Bantam Books. (10th Anniversary ed.)

Hand, S. (1989). The Levinas Reader. Oxford, UK: Blackwell.

Harste, J. C., Leland, C., Schmidt, K., Vasquez, V., \& Ociepka, A. (2004). Practice makes practice, or does it? The relationship between theory and practice in teacher education. Reading Online. 7(4).

Kirschenbaum H., Henderson V. L. (1990). The Carl Rogers Reader. London: Constable.

Koçi, A, Lazareska, A., Stankosky, M. (2012). Guidelines for Effective Introduction and Implementation of ServiceLearning in Higher Education. Macedonian National Library Skopje

Lawrenz, F., Huffman, D., Lavoie, B. (2005). Implementing and Sustaining Standards-Based Curricular Reform. National Association of Secondary School Principals. NASSP Bulletin.

Long, M. H. (2005). Second Language Needs Analysis. Cambridge University Press.

Maslow, A. (1987). Motivation and Personality.( $3^{\text {rd }}$ ed.) HarperCollins Publishers.

Milic, S. (2003). Innovations in the education system of countries in transition. Childhood Education 5:351.

Nunan, D. (1998). Syllabus Design. Oxford University Press.

Putnam, R. D. (2000). Bowling Alone: The Collapse and Revival of American Community. New York: Simon \& Schuster.

Rehling, L. (2000). Doing good while doing well: Service learning internships. Business Communication Quarterly. 63 (1).77-89.

Richards, J. C. (2001). Curriculum Development in Language Teaching. Cambridge University Press

Rogers, C. R. (1980). A Way of Being. Boston: Houghton Mifflin.

Skrtic T. M, Horn, E. M., Clark, G. M. (2009). Taking Stock of Special Education Policy \& Practice. Love Publishing Company, Denver

Sobe, N. W. (2007). U.S. Comparative Education Research on Yugoslav Education in the 1950s and 1960s . European Education. 38(4), 44-64. M.E. Sharpe, Inc.

Stier, K. W. (1997). Integrating Research into Undergraduate Coursework to Provide Professional Experiences. Journal of Construction Education, 1 (1). 15-24.

Tocqueville, Alexis. (2000). Democracy in America. The University of Chicago Press, London.

Tucker, M. L., McCarthy, A. M., Hoxmeier J. A., and Margarita, M. L. (1998). Community service learning increases communication skills across the business curriculum. Business Communication Quarterly. 61(2). 88-99.

Vygotsky, L.S. (1978). Mind in Society: Development of Higher Psychological Processes. President and Fellows of Harvard College. Harvard University

Wells, G. (2001). Action, talk, and text: learning and teaching through inquiry. Teachers College Press, Columbia University, New York, NY.

Wenden, A. (1987). Learner Strategies for Learner Autonomy. Great Britain: Prentice Hall.

Yalden, J. (1987). Principles of Course Design for Language Teaching. Cambridge University Press. 


\section{NOTES}

(1) As you can see by the name: they choose to name the Department "defectology", which has a negative connotation, and this illustrates the general attitude of people in Macedonia towards people with special needs.

(2) Item 87 High Educational institutions won't charge participation from: Parentless children, Persons with first or second degree of disability, Invalids of war and Persons that have been brought up in an Orphanage. Participation for these persons will be covered from State Universities, in the frame of students determined by the announced competition, can introduce co-financing of expenses for students whose education is not financed by the Budget of Republic of Macedonia, in agreement of the Government of Republic of Macedonia. 